\title{
THE AUDIO SCENARIO IN DRAMATURGY
}

\section{Chair: Rodrigo Meirelles - Sound Supervisor - TV Globo}

When we think of content production for drama, our references are numerous, ranging from Brazilian television programs to series and films of the international film industry. Our viewer is no different. The references have changed, the platforms and types of audience sound experience as well as the expected standard of quality. However, many of the deadlines and features are kept in the broadcasting standard of recent decades. The panel aims to discuss, with Brazilian TV and Film professionals, the efforts to raise audio quality in this new context.

- CHALLENGES OF THE MIXING AND FINALIZATION FOR CINEMA AND TV

Speaker: Ricardo Cutz - Movie Mixer - 106 db

The current context of feature films and series.

- SOUND CAPTURE IN CINEMA AND TV Speaker: Geraldo Ribeiro - Técnico de Som Direto - Cinema (G3R) Direct Sound Technician

Developments and challenges in the pursuit of quality in a recording set.

- QUALITY, DEADLINES, PROCESSES AND TECHNIQUES Speaker: Paulo Ricardo Nunes - Produtor de Áudio - Globo

The "sound of cinema" and the exclusiveness of the context of television production

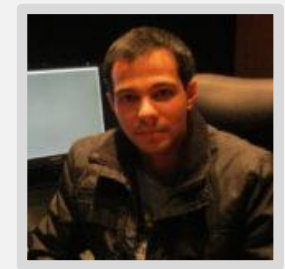

Rodrigo Meirelles - Sound Supervisor - TV Globo

Rodrigo Meirelles is Executive Supervisor of Audio of Globo. He holds a degree in Electronic Engineering and Computing, Recording and Phonographic Production and has a Masters in Education and Media. For 16 years in the audio market, he began his career as an engineer in music production studios in Rio de Janeiro, in maintenance, installation and projects of audio recording studios, he was an instructor and founder of the ProClass training center, a pioneer in official certifications In Pro Tools and Avid in Brazil, and in TV Globo, was responsible for the area 
of post-production from 2009 to 2014. Today he is responsible for the Entertainment Audio Production area (Estúdios Globo). He was a university professor for 8 years teaching courses in Phonographic Production, Audiovisual Production, Radio and TV and Graduation in Cinema.

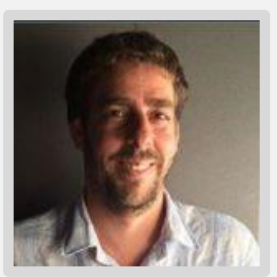

\section{Ricardo Cutz - Movie Mixer - 106 db}

Ricardo Cutz is a founding partner of $106 \mathrm{db}$. Among the recent titles edited and mixed by the 106 $\mathrm{db}$ we have: Aquarius, by Kleber Mendonça Filho, Até que a sorte nos separe 3, by Roberto Santutti and Marcelo Antunes, and Operações especiais, by Tomás Portela. In 3 years of activities, they brought to the air more than 300 episodes of renowned series such as Magnifica 70, Vai Que Cola, The Canalhas, Tempero de família, A segunda vêz, Super Bonita and Questão de família.

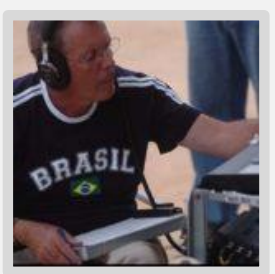

\section{Geraldo Ribeiro - Técnico de Som Direto - Cinema (G3R) Direct Sound Technician}

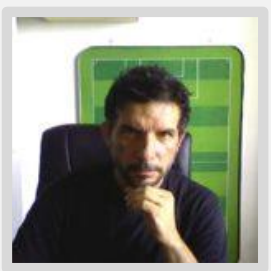

Paulo Ricardo Nunes - Produtor de Áudio - Globo 